\title{
Nitrogen content, amino acid composition and digestibility of fungi from a nutritional perspective in animal mycophagy
}

\author{
Ian R. WALLIS ${ }^{a}$, Andrew W. CLARIDGE ${ }^{b, c, *}$, James M. TRAPPE ${ }^{d, e}$

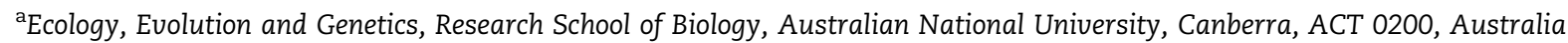 \\ ${ }^{b}$ Office of Environment and Heritage, Parks and Wildlife Group, Planning and Assessment Team, Southern Ranges Region, Queanbeyan, \\ NSW 2620, Australia \\ 'School of Physical, Environmental and Mathematical Sciences, University of New South Wales, Australian Defence Force Academy, \\ Northcott Drive, Canberra, ACT 2600, Australia \\ ${ }^{\mathrm{d}}$ Department of Forest Ecosystems and Society, Oregon State University, Corvallis, OR 97331-5752, USA \\ ${ }^{e}$ CSIRO Ecosystem Sciences, PO Box 284, Canberra, ACT 2601, Australia
}

\section{A R T I C L E I N F O}

Article history:

Received 13 November 2011

Received in revised form

10 February 2012

Accepted 18 February 2012

Available online 3 March 2012

Corresponding Editor:

Nicholas P. Money

\section{Keywords:}

Epigeous fungi

Fibre

Foregut fermentation

Hypogeous fungi

Mammals

Marsupials

Proteins

\begin{abstract}
A B S T R A C T
Fungi comprise a major part of the diet of many animals. Even so, the nutritional value of fungi has been much debated, with some arguing that fungi are nutritionally poor. However, the chemical composition of fungi and of the biology of the animals that eat them are not well understood, particularly in reference to amino acid (AA) composition of fungi and digestibility of fungal protein. We analysed fibre, total nitrogen $(\mathrm{N})$, available $\mathrm{N}$, and AA contents and measured in vitro digestibility of a wide range of epigeous and hypogeous fungi collected in Australia and the USA to test three hypotheses: (i) fungi are nutritionally poor because they contain few nutrients or are otherwise of low digestibility, (ii) fungi vary substantially in their nutritional composition; and (iii) animals can counter this variable quality by eating diverse taxa. Resultant data indicate many fungi are a reasonable source of AAs and digestible nitrogen. However, they vary highly between species in AA content, and the protein has a poor balance of digestible AAs. This helps explain why many mycophagous animals eat a wide array of fungi and often have digestive strategies to cope with fungi, such as foregut fermentation. Another common strategy is to supplement the diet with high quality protein, such as insect protein. Accordingly, evaluating nutritional value of fungi requires consideration of physiology of the animal species and their whole diet.
\end{abstract}

(c) 2012 The British Mycological Society. Published by Elsevier Ltd. All rights reserved.

\section{Introduction}

A tremendous diversity of animals eat fungi, including beetles (e.g., Hochberg et al. 2003; Newton 1984; Sutherland \& Parrella 2009), ants (Witte \& Maschwitz 2008), arthropods (Buller 1909; McGraw et al. 2002), reptiles (Cooper \& Vernes 2011; Dodd
2002), birds (Simpson 2000) and a wide range of terrestrial and partially arboreal mammals (e.g., Hanson et al. 2006; Maser et al. 1978; Vernes \& Dunn 2009). Likewise, this feeding behaviour is widespread, reported from Europe (Blaschke \& Baumler 1989), North America (Maser et al. 1978), South America (Hanson et al. 2006; Perez Calvo et al. 1989), Asia (Hanya

\footnotetext{
* Corresponding author. Office of Environment and Heritage, Parks and Wildlife Group, Planning and Assessment Team, Southern Ranges Region, Queanbeyan, NSW 2620, Australia. Tel.: +61 262997041.

E-mail address: andrew.claridge@environment.nsw.gov.au

1878-6146/\$ - see front matter @ 2012 The British Mycological Society. Published by Elsevier Ltd. All rights reserved.

doi:10.1016/j.funbio.2012.02.007
} 
2004), and Australia (Vernes \& Dunn 2009). Mycophagy particularly prevails among mammals and is best documented among flying squirrels, rats, voles and a wide variety of marsupials; often they target sporocarps of hypogeous fungi. Some animals eat mainly fungi throughout the year (Bennett \& Baxter 1989; Claridge \& May 1994; Maser et al. 1978), whereas others rely on them when other foodstuffs are scarce in the environment (Claridge \& Trappe 2005; Currah et al. 2000). Red squirrels even cache fungi when plentiful for later consumption when adequate food is scarce (Hardy 1949; Vernes \& Poirier 2007).

Claridge \& Trappe (2005) categorised animals by their relative dependence on fungi as food: (1) obligate, entirely or almost entirely dependent on fungal sporocarps; (2) preferential, prefer fungi over other dietary items but regularly or seasonally eat other types of food as well; (3) casual or opportunistic, occasionally feed on fungi as available and attractive; and (4) accidental, ingest fungal sporocarps or spores accidentally in the course of eating other foods.

Nutritional values of fungi are much debated in the scientific literature, due to a seeming mismatch between high nutrient concentrations but apparent low availability of these nutrients (Claridge \& May 1994). This led Cork \& Kenagy (1989) to ask, at the end of their paper that showed poor availability of nutrients from fungi, 'Why mycophagy?' Part of the answer came a few years later when Claridge \& Cork (1994) showed that a foregut fermenting marsupial, the long-nosed potoroo (Potorous tridactylus), digests a high proportion of the nutrients in fungi. This aside, three lines of evidence suggest that fungi are nutritionally valuable. First, in Australian eucalypt forests, $40-80 \%$ of herbivorous and omnivorous animals weighing less than $5 \mathrm{~kg}$ have diets with at least $10 \%$ fungi (Johnson 1996). A similar situation prevails among mammals in the coniferous forests of the Pacific Northwest United States (Maser et al. 1978). Second, diets of some animals, such as potoroine (rat-kangaroos) marsupials (Seebeck et al. 1990) are almost all fungi. Finally, flying squirrels, which can ill afford to fill their relatively simple gastrointestinal tracts with diets of poor digestibility, specialise in mycophagy during most times of the year (Currah et al. 2000; Flaherty et al. 2010; Lehmkuhl et al. 2004; Maser et al. 1985; Mitchell 2001; Pyare \& Longland 2001).

Even so, evidence suggests that relative to a lot of plant material, such as young leaves or seeds, fungi typically contain high concentrations of protein but much lower concentrations of energy. Thus, if the protein leverage hypothesis (Sørensen et al. 2008) holds for mammalian fungivores, we might expect them to eat excess protein to meet their essential amino acid (EAA) and energy needs. Alternatively, they may find a rich source of energy-yielding nutrients elsewhere, or mycophagy may involve matching body size with appropriate gut morphology and feeding habits to capitalise on what has been considered a poor source of nutrition (e.g. Cork \& Kenagy 1989; D'Alva et al. 2007). Digestive strategies differ between mammalian mycophagist species: species with foregut fermentation, such as the Australian potoroine and macropodid marsupials (Vernes \& Dunn 2009), can improve the nutritional value of ingested proteins through microbial fermentation. In contrast, rodents potentially obtain microbial AAs through coprophagy or caecotrophy (Soave \& Brand 1991). Also, small animals require more nutrients per unit of body mass than do larger animals but require fewer in absolute terms and thus can feed more selectively (Clauss et al. 2007).

An additional role of AAs in mycophagy is as precursors of the volatiles by which animals detect the mature fruiting bodies of hypogeous fungi. For example, methionine is a precursor of several sulphur compounds such as dimethyl sulphide and dimethyl disulphide, common to many truffle species and acting as attractants to mycophagists (Gioacchini et al. 2005; Karlovsky 2008; Splivallo et al. 2010).

To better understand relationships between mammalian fungivores and fungi, we analysed various fungal taxa with emphasis on AAs to test three hypotheses: (i) fungi are nutritionally poor because they contain few nutrients or are otherwise of low digestibility, (ii) fungi vary substantially in their nutritional composition; and (iii) animals can counter this variable quality by eating diverse taxa.

\section{Materials and methods}

\section{Source, collection and preparation of fungi}

Fungal sporocarps were collected opportunistically in Australia and the USA, often during surveys for hypogeous species which were found by raking (Claridge et al. 2000). Collections were mostly annotated and photographed at the end of the day of collection, then dried overnight on a portable electric food drier at $40{ }^{\circ} \mathrm{C}$. To get enough dry biomass for herbarium voucher collections as well as the analyses, most samples required combining several collections; consequently, the data should reasonably represent the taxon. Because hypogeous fungi fruit belowground and thus cannot be detected until exposed by raking, sample sizes differed enormously; this dictated the type and number of analyses possible for each sample (Table 1). For example, we composited samples for Protoglossum and Arcangeliella, respectively, to measure in vitro available nitrogen (AvailN), but this excluded them from the AA score because we had too little material in the same sample to analyse AAs. We partitioned protein before developing the AvailN method, so we have the information from both analyses for some samples and one or no measure for others. For samples with both measures, we have two independent $N$ values from different analyses as described later. Such limitations did not alter our overall aim of collecting as much information as possible on each species with a view to a fresh appraisal of the nutritional value of both epigeous and hypogeous taxa. For comparative purposes we included also two commercial species - dried Shiitake mushrooms (Lentinula edodes) and fresh button mushrooms (Agaricus bisporus) that we dried, as described above.

\section{Analyses}

Dried samples were divided into two replicates, then ground in a twin-blade coffee grinder and stored for later analysis in glass vials in a dark room. Prior to nutritional assay, we measured residual moisture in these samples by drying $1.0000 \pm 0.01 \mathrm{~g}$ to constant mass at $60^{\circ} \mathrm{C}$, in order to express results as a proportion of dry matter (DM). If enough sample 
Table 1 - A checklist of the species and the analyses we did on each. Measuring both the AA (AA) composition and available nitrogen (AvailN) allowed us to calculate an AA score for a sample.

\begin{tabular}{|c|c|c|c|c|c|c|c|}
\hline Species & N Partition & Leco $\mathrm{N}$ & AvailN & Cell wall & $\mathrm{AA}$ & AA score & Ash \\
\hline \multicolumn{8}{|l|}{ Hypogeous } \\
\hline Arcangeliella & & & & & $\mathrm{x}$ & & \\
\hline Arcangeliella & & & & & $\mathrm{x}$ & & \\
\hline Arcangeliella & & & & & $\mathrm{x}$ & & \\
\hline Arcangeliella & & & & & $\mathrm{x}$ & & \\
\hline Arcangeliella composite sample & & $\mathrm{x}$ & $\mathrm{x}$ & & & & \\
\hline Cortinarius globuliformis & $\mathrm{x}$ & & & $\mathrm{x}$ & $\mathrm{x}$ & & $\mathrm{x}$ \\
\hline Cortinarius globuliformis & $\mathrm{x}$ & $\mathrm{x}$ & $\mathrm{x}$ & $\mathrm{x}$ & $\mathrm{x}$ & $\mathrm{x}$ & $\mathrm{x}$ \\
\hline Cortinarius globuliformis & $\mathrm{x}$ & $\mathrm{x}$ & $\mathrm{x}$ & $\mathrm{x}$ & $\mathrm{x}$ & $\mathrm{x}$ & $\mathrm{x}$ \\
\hline Gautieria sp & & & & & $\mathrm{x}$ & & \\
\hline Gautieria monticola (immature) & $\mathrm{x}$ & & & $\mathrm{x}$ & $\mathrm{x}$ & & $\mathrm{x}$ \\
\hline Gautieria monticola (mature) & $\mathrm{x}$ & & & $\mathrm{x}$ & $\mathrm{x}$ & & $\mathrm{x}$ \\
\hline Gautieria monticola (mature) & $\mathrm{x}$ & $\mathrm{x}$ & $\mathrm{x}$ & $\mathrm{x}$ & $\mathrm{x}$ & $\mathrm{x}$ & $\mathrm{x}$ \\
\hline Gautieria monticola (mature) & $\mathrm{x}$ & $\mathrm{x}$ & $\mathrm{x}$ & $\mathrm{x}$ & $\mathrm{x}$ & $\mathrm{x}$ & $\mathrm{x}$ \\
\hline Gymnomyces sp & & & & & $\mathrm{x}$ & & \\
\hline Hysterangium coriaceum & $\mathrm{x}$ & $\mathrm{x}$ & $\mathrm{x}$ & $\mathrm{x}$ & $\mathrm{x}$ & $\mathrm{x}$ & \\
\hline Hysterangium sp & $\mathrm{x}$ & $\mathrm{x}$ & $\mathrm{x}$ & $\mathrm{x}$ & $\mathrm{x}$ & & \\
\hline Hysterangium sp & $\mathrm{x}$ & $\mathrm{x}$ & $\mathrm{x}$ & $\mathrm{x}$ & $\mathrm{x}$ & $\mathrm{x}$ & \\
\hline Mesophellia glauca & $\mathrm{x}$ & & & $\mathrm{x}$ & $\mathrm{x}$ & & \\
\hline Protoglossum sp & & & & & $\mathrm{x}$ & & \\
\hline Protoglossum sp & & & & & $\mathrm{x}$ & & \\
\hline Protoglossum sp & & & & & $\mathrm{x}$ & & \\
\hline Protoglossum sp composite sample & & $\mathrm{x}$ & $\mathrm{x}$ & & & & \\
\hline Rhizopogon hawkerae (immature) & $\mathrm{x}$ & $\mathrm{x}$ & $\mathrm{x}$ & $\mathrm{x}$ & $\mathrm{x}$ & $\mathrm{x}$ & \\
\hline Rhizopogon hawkerae (mature) & $\mathrm{x}$ & $\mathrm{x}$ & $\mathrm{x}$ & $\mathrm{x}$ & $\mathrm{x}$ & $\mathrm{x}$ & \\
\hline Rhizopogon villosulus (immature) & $\mathrm{x}$ & & & $\mathrm{x}$ & $\mathrm{x}$ & & \\
\hline Rhizopogon villosulus (immature) & $\mathrm{x}$ & $\mathrm{x}$ & $\mathrm{x}$ & $\mathrm{x}$ & $\mathrm{x}$ & $\mathrm{x}$ & \\
\hline Rhizopogon villosulus (immature) & $\mathrm{x}$ & $\mathrm{x}$ & $\mathrm{x}$ & $\mathrm{x}$ & $\mathrm{x}$ & $\mathrm{x}$ & \\
\hline Rhizopogon villosulus (immature) & $\mathrm{x}$ & $\mathrm{x}$ & $\mathrm{x}$ & $\mathrm{x}$ & $\mathrm{x}$ & $\mathrm{x}$ & \\
\hline Rhizopogon villosulus (mature) & $\mathrm{x}$ & $\mathrm{x}$ & $\mathrm{x}$ & $\mathrm{x}$ & $\mathrm{x}$ & $\mathrm{x}$ & \\
\hline Rhizopogon villosulus (mature) & $\mathrm{x}$ & $\mathrm{x}$ & $\mathrm{x}$ & $\mathrm{x}$ & $\mathrm{x}$ & $\mathrm{x}$ & \\
\hline Rhizopogon vinicolor (mature) & $\mathrm{x}$ & & & $\mathrm{x}$ & $\mathrm{x}$ & & \\
\hline Setchellogaster sp & & & & & $\mathrm{x}$ & & \\
\hline Truncocolumella citrina (immature) & $\mathrm{x}$ & $\mathrm{x}$ & $\mathrm{x}$ & $\mathrm{x}$ & $\mathrm{x}$ & $\mathrm{x}$ & \\
\hline Truncocolumella citrina (mature) & $\mathrm{x}$ & $\mathrm{x}$ & $\mathrm{x}$ & $\mathrm{x}$ & $\mathrm{x}$ & $\mathrm{x}$ & \\
\hline \multicolumn{8}{|l|}{ Epigeous } \\
\hline Agaricus bisporus & & $\mathrm{x}$ & $\mathrm{x}$ & & $\mathrm{x}$ & & \\
\hline Agaricus xanthodermus & & $\mathrm{x}$ & $\mathrm{x}$ & & $\mathrm{x}$ & & \\
\hline Boletus edulis & $\mathrm{x}$ & $\mathrm{x}$ & $\mathrm{x}$ & $\mathrm{x}$ & $\mathrm{x}$ & $\mathrm{x}$ & $\mathrm{x}$ \\
\hline Boletus edulis & & & & & $\mathrm{x}$ & & \\
\hline Boletus mirabilis & $\mathrm{x}$ & & & $\mathrm{x}$ & $\mathrm{x}$ & & $\mathrm{x}$ \\
\hline Boletus mirabilis & & & & & $\mathrm{x}$ & & \\
\hline Cantharellus formosus & & & & & $\mathrm{x}$ & & \\
\hline Cantharellus formosus & & & & & $\mathrm{x}$ & & \\
\hline Cantharellus formosus & $\mathrm{x}$ & $\mathrm{x}$ & $\mathrm{x}$ & $\mathrm{x}$ & $\mathrm{x}$ & $\mathrm{x}$ & $\mathrm{x}$ \\
\hline Cantharellus formosus & $\mathrm{x}$ & $\mathrm{x}$ & $\mathrm{x}$ & $\mathrm{x}$ & $\mathrm{x}$ & $\mathrm{x}$ & $\mathrm{x}$ \\
\hline Cantharellus formosus & $\mathrm{x}$ & $\mathrm{x}$ & $\mathrm{x}$ & $\mathrm{x}$ & $\mathrm{x}$ & $\mathrm{x}$ & $\mathrm{x}$ \\
\hline Cantharellus subalbidus & $\mathrm{x}$ & $\mathrm{x}$ & $\mathrm{x}$ & $\mathrm{x}$ & $\mathrm{x}$ & $\mathrm{x}$ & $\mathrm{x}$ \\
\hline Cantharellus subalbidus & $\mathrm{x}$ & & & $\mathrm{x}$ & $\mathrm{x}$ & & $\mathrm{x}$ \\
\hline Lentinula edodes & & $\mathrm{x}$ & $\mathrm{x}$ & & $\mathrm{x}$ & & \\
\hline Morchella elata & & & & & $\mathrm{x}$ & & \\
\hline Morchella elata & & & & & $\mathrm{x}$ & & \\
\hline Morchella elata (immature) & $\mathrm{x}$ & $\mathrm{x}$ & $\mathrm{x}$ & $\mathrm{x}$ & $\mathrm{x}$ & & $\mathrm{x}$ \\
\hline Morchella elata & $\mathrm{x}$ & & & $\mathrm{x}$ & $\mathrm{x}$ & & $\mathrm{x}$ \\
\hline Morchella elata & $\mathrm{x}$ & $\mathrm{x}$ & $\mathrm{x}$ & $\mathrm{x}$ & $\mathrm{x}$ & & \\
\hline Morchella elata & $\mathrm{x}$ & & & $\mathrm{x}$ & $\mathrm{x}$ & & $\mathrm{x}$ \\
\hline Tricholoma magnivelare & & $\mathrm{x}$ & $\mathrm{x}$ & & $\mathrm{x}$ & & \\
\hline Tricholoma magnivelare & & & & & $\mathrm{x}$ & & \\
\hline Tricholoma magnivelare & & & & & $\mathrm{x}$ & & \\
\hline Tricholoma magnivelare & & & & & $\mathrm{x}$ & & \\
\hline Tricholoma magnivelare & & & & & $\mathrm{x}$ & & \\
\hline Tricholoma magnivelare & $\mathrm{x}$ & $\mathrm{x}$ & $\mathrm{x}$ & $\mathrm{x}$ & $\mathrm{x}$ & $\mathrm{x}$ & $\mathrm{x}$ \\
\hline Tricholoma magnivelare & $\mathrm{x}$ & $x$ & $\mathrm{x}$ & $\mathrm{x}$ & $\mathrm{x}$ & $\mathrm{x}$ & $x$ \\
\hline
\end{tabular}


Table 1 - (continued)

\begin{tabular}{lccccccc} 
Species & N Partition & Leco N & AvailN & Cell wall & AA & AA score & Ash \\
\hline Tricholoma magnivelare & $\mathrm{x}$ & $\mathrm{x}$ & $\mathrm{x}$ & $\mathrm{x}$ & $\mathrm{x}$ & $\mathrm{x}$ & $\mathrm{x}$ \\
Tricholoma magnivelare & $\mathrm{x}$ & $\mathrm{x}$ & $\mathrm{x}$ & $\mathrm{x}$ & $\mathrm{x}$ & $\mathrm{x}$ & $\mathrm{x}$ \\
Tricholoma magnivelare & $\mathrm{x}$ & $\mathrm{x}$ & $\mathrm{x}$ & $\mathrm{x}$ & $\mathrm{x}$ & $\mathrm{x}$ & $\mathrm{x}$ \\
Tricholoma magnivelare & $\mathrm{x}$ & $\mathrm{x}$ & $\mathrm{x}$ & $\mathrm{x}$ & $\mathrm{x}$ & $\mathrm{x}$ & $\mathrm{x}$ \\
\hline
\end{tabular}

remained we then determined ash (mineral) content by weighing after ignition at $600^{\circ} \mathrm{C}$ for $12 \mathrm{~h}$.

\section{Cell-wall material}

Concentrations of cell-wall material (fibre) were extracted with pepsin in citrate buffer at $4{ }^{\circ} \mathrm{C}$ for $24 \mathrm{~h}$ (Faichney \& White 1983) to remove protein and then with neutral detergent solution (Goering \& Van Soest 1970), without sodium sulfite, for $3 \mathrm{~h}$ at $98^{\circ} \mathrm{C}$ in tubes immersed in a boiling water bath to remove remaining cell contents.

\section{Nitrogen}

Total $N$ content of fungal samples was determined in two ways. To partition $\mathrm{N}$ we used a micro-Kjeldahl digestion followed by distillation and auto-analysis of the resulting ammonia (Williams \& Twine 1967). Values for total $N$ from these samples are likely underestimated, because the digestion technique does not measure nitrate- $\mathrm{N}$. Total $\mathrm{N}$ in sporocarps was partitioned as follows. (1) Cell-wall $N$ was analysed on the residue after extraction with pepsin and neutral detergent; (2) N from protein and cell wall was analysed by extracting samples with $5 \%(\mathrm{~m} / \mathrm{v})$ trichloroacetic acid (to remove non-protein $\mathrm{N}$, which, unlike protein, is not precipitated by TCA), centrifugation and removal of the supernatant liquid, and analysis of the residue by micro-Kjeldahl digestion (Faichney \& White 1983).

To measure AvailN described later, we used a Leco Truspec Carbon/Nitrogen Determinator (St. Joseph, U.S.A.) calibrated with EDTA and corn flour using $200 \pm 10 \mathrm{mg}$ of sample to determine $N$ content of the dried fungus and $100 \pm 10 \mathrm{mg}$ to determine the $\mathrm{N}$ in the residue at the end of the in vitro digestion.

\section{Amino acids (AAs)}

Concentrations of AAs in fungi were determined by first hydrolysing samples (500 $\pm 1 \mathrm{mg}$ ) according to Llames \& Fontaine (1994) and then separating AAs by HPLC by the method of Cohen \& Michaud (1993), essentially the AccQ.Tag ${ }^{\text {TM }}$ method (Waters, Milford, MA, USA). We used $\alpha$-amino-butyric acid as an internal standard and separated AAs using an AccQ.Tag ${ }^{\mathrm{TM}}$ column $\left(150 \times 3.9 \mathrm{~mm}\right.$ Nova-Pak ${ }^{\mathrm{TM}} \mathrm{C}_{18}, 4 \mu \mathrm{m}$ particle size; Waters, Milford, Massachusetts). The column was held at $37^{\circ} \mathrm{C}$ on a Waters HPLC consisting of a 600 controller, a 717 autosampler, and a 474 fluorescence detector set to an excitation wavelength of $250 \mathrm{~nm}$, emission wavelength of $250 \mathrm{~nm}$, filter of 0.5 , and gain of 100 . AAs were quantified by determining the response factor for each based on running six independently prepared AA standards (AA-S-18; Sigma, NSW, Australia) to which we added internal standard. Acid hydrolysis destroys methionine, so we do not report results for that AA.

\section{AvailN and dry matter digestibility (DMD)}

We determined in vitro AvailN and DMD in duplicate by the method of DeGabriel et al. (2008) that mimics digestion in a model herbivore. The purpose of the assay was to rank fungi with regard to AvailN and DMD rather than trying to give precise in vivo values for these constituents. The assay involved duplicate digestions of the samples $(0.8050 \pm 0.0050 \mathrm{~g})$ in porous bags (Ankom F57, Ankom Technology, Macedon, New York) at $35^{\circ} \mathrm{C}$, first with pepsin (24 h) and then with cellulase (48 h). Knowing the mass of DM in the bag at the end of the assay enabled us to estimate $\mathrm{DMD}$, while analysing this residue for $\mathrm{N}$ gave us values for the digestibility of $\mathrm{N}$ and AvailN.

Although we cannot find records of fungi producing tannins, we tested this possibility by incubating two bags per sample for $24 \mathrm{~h}$ either with the tannin-binding agent, polyethylene glycol MW 4000 (33.3 $\mathrm{g} \mathrm{L}^{-1}$ in $0.05 \mathrm{M}$ Tris-BASE buffer), or with buffer alone (both $25 \mathrm{~mL} \mathrm{sample}^{-1}$ ) at the start of the digestion. We then thoroughly washed the bags before drying them to constant mass at $50{ }^{\circ} \mathrm{C}$ and weighing them. We call the loss of mass, in this initial step, 'solubles'.

\section{EAA score}

To assess fungal protein quality we calculated an AA score as follows:

$$
\begin{aligned}
\text { EAA score }= & \text { in vitro } \mathrm{N} \text { digestibility } \\
& *\left({\text { EAA } \mathrm{mg} \mathrm{g}^{-1} \text { protein in fungus } /}\right. \\
& \text { EAA } \left.\mathrm{mg} \mathrm{g}^{-1} \text { protein in standard }\right)
\end{aligned}
$$

We included two non-essential AAs in the calculation, arginine because of potential antagonism with lysine (e.g., Jones et al. 1966) and tyrosine, because animals require aromatic AAs - tyrosine plus phenylalanine (e.g., Benevenga et al. 1994). The logic behind the calculation is that most animals need the same relative proportions of AAs for protein synthesis, while the absolute amount of AAs they need depends on their requirement for protein and digestibility of AAs they ingest (Boisen et al. 2000). We used the EAA requirement for rat growth (NRC 1995) to gauge quality of the fungal protein. As this calculation depended on a measure of $N$ digestibility, we calculated the EAA score only for the 30 samples analysed also for AvailN. This calculation assumes that all AAs in the sample are of similar digestibility, as determined by digestibility of $\mathrm{N}$ in the sample.

\section{Statistical analysis}

We used GenStat Release 10.2, Lawes Agricultural Trust (Rothamsted Experimental station) for all statistical analyses, 
which were largely descriptive. We used the unbalanced analysis of variance command to test differences in nutritional composition between hypogeous and epigeous taxa, transforming data where necessary to meet requirements of parametric statistics. Mean values were used for taxa represented by several samples. We tabulated results for each sample unless there were two or more samples for a species, whereby we show the mean, standard deviation (sd), and the number $(N)$ of samples.

\section{Results}

\section{Cell walls, soluble material, in vitro DMD, and ash}

Epigeous and hypogeous fungi were similarly variable (coefficient of variation, $\mathrm{CV}=24 \%$ and $17 \%$ ) in their concentrations of cell wall material but epigeous fungi had significantly lower mean concentrations than did hypogeous taxa (27.2 versus $51.2 \% \mathrm{DM} ; \mathrm{P}<0.001$; Table 2). This was reflected in epigeous fungi having much higher mean concentrations of soluble material (58 versus $39 \% \mathrm{DM}$ ) and much higher mean DMD (mean 77.3 versus $62.0 \% \mathrm{DM}$ ) (Table 3 ). The concentration of soluble material was closely related to that of DMD across all fungal taxa $\left(r^{2}=87, F_{1,30}=206, P<0.0001\right)$. We had too little material from hypogeous fungi to statistically compare ash contents. That said, three samples of Cortinarius globuliformis all contained a high proportion of ash (mean $27 \%$ ). The low CV (3.0\%) of this mean and care when collecting samples suggests a real value rather than contamination with soil. In contrast, mean ash content across seven epigeous species was around one-third that of C. globuliformis (mean 9.1\%) (Table 2).

\section{Nitrogen, AvailN, and nitrogen partitioning}

$\mathrm{N}$ values agreed well whether obtained by Kjeldahl analysis or combustion analysis $\left(r^{2}=0.92, F_{1,24}=271, P<0.0001\right.$; Intercept $=-0.107, \quad P=0.49 ;$ Slope $=1.20,95 \%$ $\mathrm{CI}=1.05-1.35 ; \mathrm{P}<0.0001)$. Kjeldahl $\mathrm{N}$ does not measure nitrate and nitrite ions unless they are reduced before acid digestion, so we expected the slope to exceed 1.

Nitrogen values (\% DM) ranged from 1.98 (10.6\% crude protein, CP) for Gautieria monticola to 8.39 (52.5\% CP) for Agaricus xanthodermus (Table 3), with an overall mean of $3.75 \% \mathrm{~N}$ (23.4\% CP). Epigeous fungi contained significantly more $\mathrm{N}$ than did the hypogeous fungi both in the samples used to measure AvailN (4.59 versus $2.70 \% \mathrm{~N} \mathrm{DM}$; $\mathrm{P}=0.016$ ) (Table 3) and in those used to partition N (3.44 versus $2.36 \% \mathrm{~N} \mathrm{DM}$; $P=0.015$ ) (Table 2). In the former data, Agaricus bisporus (6.3\%N DM), A. xanthoderma (8.39\%N DM) and Boletus edulis $(6.21 \%)$ inflated the mean. The cell contents from hypogeous and epigeous fungi had similar concentrations of $\mathrm{N}$ (mean $=4.04$ and $4.47 \% \mathrm{~N} \mathrm{DM} ; \mathrm{P}=0.54$ ), although values varied more among the latter $(\mathrm{CV}=40$ versus $23 \%)$ (Table 2$)$. These concentrations were much higher than that of $N$ in the cell walls, which differed significantly $(P=0.037)$ between hypogeous $(0.61 \% \mathrm{~N} \mathrm{DM}$; CV $=50 \%)$ and epigeous taxa $(0.34 \%$ $\mathrm{N} \mathrm{DM} ; \mathrm{CV}=44 \%$ ). Because hypogeous fungi contained more cell wall material rich in $N$, a larger proportion of the $N$ in these fungi occurred in the cell walls than in epigeous fungi
(4.1 versus $14.4 \% ; F_{1,19}=11.4, P=0.003$ ). Even so, overall digestibility of $\mathrm{N}$ did not differ between hypogeous and epigeous taxa (73.9\% versus $71.3 \% ; P=0.65)$ (Table 3). Except for Hysterangium sp., where $N$ digestibility was only $39 \%$, more than half of the $N$ in all other fungal species was digestible (55.1-84.1\%) (Table 3). The similar digestibility of $N$ in the two groups meant that concentration of AvailN (Total $N^{*}$ digestibility of $N$ ) depended on total $N$ concentration and so was higher in epigeous (4.57\% DM) than in hypogeous (2.07\% DM) taxa (data from AvailN assay only). If mean $N$ digestibility was the same for taxa used in the $N$ partition assay, then the corresponding AvailN values for those data would be 1.7 and $2.5 \% \mathrm{~N} \mathrm{DM}$ for hypogeous and epigeous taxa, respectively. In contrast to expectations, the digestibility of $\mathrm{N}$ was not related to either DMD or the concentration of soluble material.

Tannins are unknown from fungi and thus values for $\mathrm{N}$ digestibility from samples incubated with buffer were generally similar to those for corresponding samples incubated with buffer plus PEG. There was, however, one exception. The digestibility of $N(81.2 \%)$ and thus available $N(1.805 \% \mathrm{DM})$ was much higher in Hysterangium coriaceum incubated with PEG than without PEG (67.2 \%, $1.496 \%$ DM). Reanalysis confirmed the result.

Between $67 \%$ and $93 \%$ of the $\mathrm{N}$ in hypogeous species occurred as protein, whereas the range was much greater for epigeous taxa (18-81\%) (Table 2). The mean proportion of protein $\mathrm{N}$ was lower for epigeous species (55 versus $72 \%$; $P=0.016)$, largely due to low values for the two Boletus species $-B$. edulis and B. mirabilis (18 and $32 \% \mathrm{~N}$ as protein, respectively).

\section{AA concentrations}

For all taxa for which we had the concentrations of both AAs and $\mathrm{N}$, there was a significant relationship between the traits for all AAs $(P<0.0001)$. In keeping with their higher concentrations of $\mathrm{N}$, species of epigeous fungi tended to have higher concentrations of most AAs than hypogeous taxa ( $P$ values ranging from 0.05 to 0.01 ) (Table 4). The exceptions were aspartic acid and histidine, the concentrations of which did not differ significantly between the fungal forms, although the $P$ values $(0.10$ and 0.13$)$ suggested a trend. In contrast, there was no relationship $(P>0.5)$ between the concentration of protein- $\mathrm{N}$ and that of individual AAs for the 18 taxa for which we had paired data. This was largely due to low concentrations of protein-N but high concentrations of AAs in the Boletus species, suggesting that a substantial quantity of AAs in these taxa existed in the free form. Removing these values improved the relationship, but taxa still had much lower AA concentrations than expected, with mature Rhizopogon hawkerae a prime example (Table 4). A repeat analysis confirmed our original concentrations.

\section{AA balance}

The concentrations of AAs corrected for in vitro digestibility of $N$ suggest that fungal protein is of poor quality for rats. Expressed relative to that of ideal protein, most fungi supply about $50 \%$ of the rat's requirements for each EAA (Table 5). The most commonly limiting EAA is lysine, of which epigeous 
Table 2 - The concentrations of cell walls, total nitrogen $(\mathbf{N}), \mathbf{N}$ in cell walls and cell contents (\% DM) and the partition of $\mathbf{N}$ between protein and non-protein.

\begin{tabular}{|c|c|c|c|c|c|c|c|c|}
\hline Species & & Ash \% & $\begin{array}{c}\text { Cell } \\
\text { Wall \% }\end{array}$ & $\mathrm{N} \%$ & $\begin{array}{c}\text { Cell } \\
\text { Wall N \% }\end{array}$ & $\begin{array}{c}\text { Cell } \\
\text { cont. } \mathrm{N} \%^{\mathrm{a}}\end{array}$ & $\begin{array}{l}\text { Prot. } \\
N \%{ }^{b}\end{array}$ & $\begin{array}{c}\text { Prot. } \\
\mathrm{N} \% / \mathrm{N} \%{ }^{\mathrm{c}}\end{array}$ \\
\hline \multicolumn{9}{|l|}{ Hypogeous } \\
\hline \multirow[t]{2}{*}{ Cortinarius globuliformis $(\mathrm{N}=3)$} & Mean & 27.9 & 49.8 & 1.63 & 0.39 & 2.98 & 1.20 & 0.74 \\
\hline & sd & 1.2 & 3.28 & 0.17 & 0.05 & 0.31 & 0.14 & 0.02 \\
\hline Gautieria monticola (immat) & & 6.3 & 57.0 & 2.38 & 0.36 & 5.27 & 1.61 & 0.67 \\
\hline \multirow[t]{2}{*}{ Gautieria monticola (mat) $(N=3)$} & Mean & 5.5 & 69.0 & 2.00 & 0.53 & 5.79 & 1.40 & 0.72 \\
\hline & sd & 0.78 & 5.9 & 0.41 & 0.26 & 1.11 & 0.27 & 0.04 \\
\hline Hysterangium coriaceum & & & 59.0 & 2.07 & 0.82 & 4.41 & 1.48 & 0.71 \\
\hline \multirow[t]{2}{*}{ Hysterangium sp $(\mathrm{N}=2)$} & Mean & & 49.6 & 3.01 & 1.06 & 5.32 & 2.03 & 0.68 \\
\hline & sd & & 6.4 & 0.02 & 0.14 & 0.63 & 0.02 & 0.00 \\
\hline Mesophellia glauca & & & 53.4 & 2.18 & 1.23 & 3.83 & 1.76 & 0.81 \\
\hline Rhizopogon hawkerae (immat) & & & 43.8 & 3.07 & 0.37 & 5.25 & 2.38 & 0.78 \\
\hline Rhizopogon hawkerae (mat) & & & 49.9 & 1.85 & 0.59 & 3.31 & 1.72 & 0.93 \\
\hline \multirow[t]{3}{*}{ Rhizopogon villosulus (immat) $(\mathrm{N}=4)$} & Mean & & 47.7 & 2.62 & 0.42 & 4.75 & 1.72 & 0.67 \\
\hline & sd & & 4.8 & 0.61 & 0.06 & 0.99 & 0.33 & 0.06 \\
\hline & $\mathrm{CV} \%$ & & 10 & 23 & 14 & 21 & 19 & 9 \\
\hline \multirow{2}{*}{ Rhizopogon villosulus (mat) $(\mathrm{N}=2)$} & Mean & & 48.3 & 1.94 & 0.51 & 3.43 & 1.29 & 0.67 \\
\hline & sd & & 3.8 & 0.20 & 0.00 & 0.13 & 0.17 & 0.02 \\
\hline Rhizopogon vinicolor (mat) & & & 62.2 & 1.81 & 0.59 & 4.29 & 1.23 & 0.68 \\
\hline Truncocolumella citrina (immat) & & & 43.4 & 2.23 & 0.32 & 3.76 & 1.53 & 0.69 \\
\hline Truncocolumella citrina (mat) & & & 34.8 & 1.94 & 0.34 & 2.75 & 1.28 & 0.673 \\
\hline \multicolumn{9}{|l|}{ Epigeous } \\
\hline Boletus edulis & & 7.1 & 18.7 & 5.78 & 0.22 & 7.02 & 1.06 & 0.18 \\
\hline Boletus mirabilis & & 7.8 & 24.6 & 4.67 & 0.27 & 6.08 & 1.51 & 0.32 \\
\hline \multirow{2}{*}{ Cantharellus formosus $(\mathrm{N}=3)$} & Mean & 10.8 & 32.0 & 2.21 & 0.53 & 3.02 & 1.71 & 0.77 \\
\hline & sd & 0.47 & 1.41 & 0.19 & 0.03 & 0.26 & 0.10 & 0.06 \\
\hline \multirow[t]{2}{*}{ Cantharellus subalbidus $(\mathrm{N}=2)$} & Mean & 10.4 & 36.0 & 1.69 & 0.55 & 2.37 & 1.37 & 0.81 \\
\hline & sd & 0.16 & 1.41 & 0.11 & 0.09 & 0.19 & 0.02 & 0.04 \\
\hline Morchella elata (immat) & & 9.6 & 24.0 & 4.15 & 0.28 & 5.34 & 2.26 & 0.54 \\
\hline \multirow[t]{2}{*}{ Morchella elata $(\mathrm{N}=3)$} & Mean & 10.2 & 21.9 & 3.63 & 0.27 & 4.54 & 2.17 & 0.60 \\
\hline & sd & 0.95 & 7.98 & 0.10 & 0.11 & 0.48 & 0.12 & 0.03 \\
\hline \multirow[t]{3}{*}{ Tricholoma magnivelare $(\mathrm{N}=6)$} & Mean & 8.1 & 33.0 & 1.96 & 0.24 & 2.82 & 1.18 & 0.60 \\
\hline & sd & 0.77 & 3.30 & 0.21 & 0.05 & 0.31 & 0.13 & 0.02 \\
\hline & $\mathrm{CV} \%$ & 10 & 10 & 11 & 21 & 11 & 13 & 3 \\
\hline \multicolumn{2}{|l|}{ Mean (hypogeous) } & 13.2 & 51.2 & 2.36 & 0.61 & 4.04 & 1.62 & 0.72 \\
\hline \multicolumn{2}{|l|}{ Standard deviation } & 12.7 & 8.7 & 0.48 & 0.31 & 0.92 & 0.35 & 0.07 \\
\hline \multicolumn{2}{|l|}{$\mathrm{CV} \%$} & 96 & 17 & 20 & 51 & 23 & 22 & 10 \\
\hline \multicolumn{2}{|l|}{ Mean (epigeous) } & 9.1 & 27.2 & 3.44 & 0.34 & 4.47 & 1.61 & 0.55 \\
\hline \multicolumn{2}{|l|}{ Standard deviation } & 1.5 & 6.5 & 1.54 & 0.14 & 1.81 & 0.46 & 0.23 \\
\hline \multicolumn{2}{|l|}{$\mathrm{CV} \%$} & 16 & 24 & 45 & 41 & 40 & 29 & 42 \\
\hline \multicolumn{2}{|l|}{ Epigeous versus hypogeous } & ns & 41.3 & 7.2 & 5.03 & ns & ns & 7.05 \\
\hline \multicolumn{9}{|l|}{$F_{1,19}\left(F_{1,9}\right.$ for ash $)$} \\
\hline \multicolumn{2}{|l|}{$P$} & 0.39 & $<0.001$ & 0.015 & 0.037 & 0.54 & 0.95 & 0.016 \\
\hline \multicolumn{3}{|l|}{ Least significant difference (5 \%) } & 7.84 & 0.925 & 0.259 & & & 0.098 \\
\hline
\end{tabular}

and hypogeous fungi supply on average $35 \%$ and $43 \%$ of the rat's requirements. Other AAs, especially arginine $(76 \%$ and $86 \%)$ and, in the case of epigeous taxa, the sum of phenylalanine and tyrosine (95\%), provide much higher proportions of the requirements, suggesting imbalanced protein.

\section{Variation within and among fungi}

Irrespective of whether fungi were epigeous or hypogeous, the chemical composition of their sporocarps varied widely (Tables 2-4). For example, across the different species of hypogeous fungi CVs were high ( $>40 \%$ ) for ash, cell-wall $N$ and most AAs. Among epigeous fungi, CVs were also similarly high for AAs, as well as N, cell-wall N, cell-contents $\mathrm{N}$ and AvailN.

The limited data show that variation for some nutritional properties is much lower within taxa than among taxa. For example, from Table 5 data it is evident that the CV for many AAs is lower from samples averaged within species than averaged across species. This is particularly so for epigeous species such as Cantharellus formosus and Tricholoma magnivelare, where multiple collections were available for analysis, compared to values averaged across all epigeous species. 
Table 3 - The concentrations of nitrogen (N), solubles and available nitrogen (AvailN) along with the digestibilities of dry matter (DMD) and nitrogen (Ndig). All are \% dry matter.

\begin{tabular}{|c|c|c|c|c|c|c|}
\hline Species & & $N$ & Solubles & DMD & Ndig & AvailN \\
\hline \multicolumn{7}{|l|}{ Hypogeous } \\
\hline Arcangeliella (composite) & & 3.98 & 43 & 62.7 & 67.3 & 2.66 \\
\hline \multirow[t]{2}{*}{ Cortinarius globuliformis $(\mathrm{N}=2)$} & Mean & 1.78 & 40 & 58.1 & 77.1 & 1.36 \\
\hline & sd & 0.04 & 4 & 7.3 & 2.0 & 0.06 \\
\hline Gautieria monticola (mat) $(N=2)$ & Mean & 1.98 & 18 & 41.4 & 76.2 & 1.50 \\
\hline Gautieria monticola (mat) & sd & 0.38 & 3 & 5.6 & 3.0 & 0.22 \\
\hline Hysterangium coriaceum & & 2.23 & 24 & 50.3 & 81.2 & 1.80 \\
\hline Hysterangium sp & & 3.52 & 24 & 45.2 & 39.4 & 1.38 \\
\hline Protoglossum sp (composite) & & 2.99 & 47 & 62.5 & 64.2 & 1.90 \\
\hline Rhizopogon hawkerae (immature) & & 3.73 & 40 & 71.0 & 76.1 & 2.84 \\
\hline Rhizopogon hawkerae (mat) & & 2.08 & 47 & 75.2 & 81.0 & 1.67 \\
\hline \multirow[t]{2}{*}{ Rhizopogon villosulus (immat) $(\mathrm{N}=3)$} & Mean & 3.34 & 43 & 68.9 & 77.1 & 2.58 \\
\hline & sd & 0.78 & 0.2 & 4.0 & 4.8 & 0.50 \\
\hline \multirow[t]{2}{*}{ Rhizopogon villosulus (mat) $(N=2)$} & Mean & 2.15 & 45 & 68.8 & 84.1 & 1.79 \\
\hline & sd & 0.23 & 5 & 3.58 & 1.2 & 0.16 \\
\hline Truncocolumella citrina (immat) & & 2.57 & 42 & 65.1 & 80.2 & 2.06 \\
\hline Truncocolumella citrina (mat) & & 2.15 & 55 & 75.2 & 85.1 & 1.83 \\
\hline \multicolumn{7}{|l|}{ Epigeous } \\
\hline Agaricus bisporus & & 6.30 & 71 & 85.1 & 64.2 & 4.04 \\
\hline Agaricus xanthodermus & & 8.39 & 66 & 88.3 & 73.2 & 6.15 \\
\hline Boletus edulis & & 6.21 & 57 & 82.8 & 79.2 & 4.90 \\
\hline \multirow[t]{2}{*}{ Cantharellus formosus $(\mathrm{N}=3)$} & Mean & 2.57 & 51 & 67.7 & 55.1 & 1.41 \\
\hline & sd & 0.225 & 4 & 2.57 & 1.51 & 0.109 \\
\hline Cantharellus subalbidus & & 1.92 & 51 & 66.3 & 62.1 & 1.18 \\
\hline Lentinula edodes & & 3.80 & 53 & 76.3 & 84.3 & 3.17 \\
\hline \multirow[t]{3}{*}{ Tricholoma magnivelare $(\mathrm{N}=7)$} & Mean & 2.36 & 56 & 74.7 & 82.2 & 1.93 \\
\hline & sd & 0.256 & 2.3 & 3.16 & 1.32 & 0.213 \\
\hline & $\mathrm{CV} \%$ & 11 & 4 & 4 & 2 & 11 \\
\hline Mean (hypogeous) & & 2.70 & 39 & 62.0 & 73.9 & 1.95 \\
\hline Standard deviation (hypogeous) & & 0.77 & 11 & 11.2 & 12.6 & 0.50 \\
\hline CV \% & & 29 & 28 & 18 & 17 & 26 \\
\hline Mean (epigeous) & & 4.59 & 58 & 77.3 & 71.3 & 3.26 \\
\hline Standard deviation (epigeous) & & 2.30 & 8 & 8.5 & 11.1 & 1.88 \\
\hline $\mathrm{CV} \%$ & & 50 & 14 & 11 & 16 & 58 \\
\hline Epigeous versus hypogeous $F_{1,18}$ & & 7.00 & 16.2 & 9.8 & ns & 5.39 \\
\hline$P$ & & 0.016 & $<0.001$ & 0.006 & 0.65 & 0.033 \\
\hline Least significant difference (5 \%) & & 1.49 & 0.098 & 10.3 & & 1.189 \\
\hline
\end{tabular}

\section{Discussion}

Our nutritional analyses give resounding answers to the three hypotheses we posed: (i) fungi are nutritionally poor because they contain few nutrients or are otherwise of low digestibility, (ii) fungi vary substantially in their nutritional composition, and (iii) animals can counter this variable quality by eating diverse taxa. First, in agreement with other published literature (e.g., Claridge \& Cork 1994; Fogel \& Trappe 1978; Grönwall \& Pehrson 1984; Kalac 2009; Singer 1961) we found that both epigeous and hypogeous fungi are a potentially rich source of nutrients, on average rejecting hypothesis (i). Our assays, which concentrated on nitrogenous components, indicated that most of the $\mathrm{N}$ in fungi occurs as protein and, in some cases, notably Boletus sp., a substantial amount occurs as free AAs. However, as pointed out by Cork \& Kenagy (1989), the key interest is not total concentration of a nutrient but instead concentration of available nutrients in the food. To that extent, our in vitro digestibility analysis showed that the fungi contain much material (ca $50 \%$ ) soluble in buffer, whereas about $70 \%$ of the total DM and the $\mathrm{N}$ are capable of being digested. Considering they are from an in vitro assay, these results show reasonable agreement with some of the results from the few studies in which researchers have fed fungi to animals to measure digestibility or availability of nutrients. These include the findings of Claridge \& Cork (1994) who fed two species of hypogeous fungi to the long-nosed potoroo, a foregut-fermenting marsupial; Claridge et al. (1999), who fed a single species of hypogeous fungus to red-backed voles and flying squirrels; and D'Alva et al. (2007), who fed epigeous Russula to deer mice and volcano mice. While our DMD values are similar to these published values, our $N$ digestibility values are much higher than those of Cork \& Kenagy (1989), who fed the hypogeous Elaphomyces granulatus to ground squirrels ( $\mathrm{N}$ digestibility $=30 \%$ ) and Dubay et al. (2008) who fed hypogeous fungi to red-backed voles $(\mathrm{N}$ digestibility $=12.5 \%)$ and flying squirrels $(\mathrm{N}$ digestibility $=24.9 \%$ ). Difficulties in obtaining sufficient fungi for feeding in this last study forced very short digestion trials, where endpoint errors are likely large. This makes it difficult 
Table 4 - The concentration of amino acids (AAs) in fungi (\% dry matter). The values are for individual samples or means and standard deviation (sd) of $\mathrm{N}$ samples when

we analysed more than two different collections of a taxon.

\begin{tabular}{|c|c|c|c|c|c|c|c|c|c|c|c|c|c|c|c|c|c|}
\hline Species & & Asp $^{a}$ & Ser & Glu & Gly & His & Arg & Thr & Ala & Pro & Tyr & Val & Lys & Ile & Leu & Phe & $\mathrm{EAA}^{\mathrm{b}}$ \\
\hline \multicolumn{18}{|l|}{ Hypogeous species } \\
\hline \multirow[t]{2}{*}{ Arcangeliella $(\mathrm{N}=3)$} & Mean & 1.78 & 0.93 & 3.36 & 0.87 & 0.58 & 1.32 & 0.89 & 1.29 & 1.11 & 0.60 & 0.99 & 1.03 & 0.75 & 1.37 & 0.83 & 7.04 \\
\hline & sd & 0.11 & 0.07 & 0.18 & 0.04 & 0.05 & 0.4 & 0.05 & 0.13 & 0.08 & 0.02 & 0.07 & 0.09 & 0.05 & 0.10 & 0.02 & 0.45 \\
\hline \multirow[t]{2}{*}{ Cortinarius globuliformis $(\mathrm{N}=3)$} & Mean & 0.38 & 0.18 & 0.71 & 0.22 & 0.06 & 0.18 & 0.09 & 0.24 & 0.13 & 0.1 & 0.12 & 0.15 & 0.09 & 0.13 & 0.07 & 0.81 \\
\hline & sd & 0.09 & 0.04 & 0.03 & 0.03 & 0 & 0.02 & 0.02 & 0.07 & 0.04 & 0.02 & 0.05 & 0.03 & 0.03 & 0.03 & 0.02 & 0.20 \\
\hline \multirow[t]{2}{*}{ Gautieria monticola (immature) $(N=2)$} & Mean & 0.98 & 0.58 & 1.66 & 0.64 & 0.41 & 0.57 & 0.55 & 0.68 & 0.64 & 0.35 & 0.59 & 0.54 & 0.50 & 0.77 & 0.46 & 4.16 \\
\hline & sd & 0.01 & 0.08 & 0.37 & 0.08 & 0.21 & 0.01 & 0.04 & 0.01 & 0.07 & 0.04 & 0.00 & 0.01 & 0.02 & 0.01 & 0.01 & 0.25 \\
\hline \multirow[t]{2}{*}{ Gautieria monticola (mature) $(\mathrm{N}=3)$} & Mean & 0.97 & 0.58 & 1.65 & 0.64 & 0.41 & 0.57 & 0.55 & 0.68 & 0.64 & 0.35 & 0.59 & 0.28 & 0.34 & 0.47 & 0.33 & 3.32 \\
\hline & sd & 0.01 & 0.07 & 0.37 & 0.09 & 0.22 & 0.02 & 0.05 & 0 & 0.07 & 0.04 & 0.01 & 0.06 & 0.06 & 0.1 & 0.07 & 0.61 \\
\hline Gymnomyces & & 1.69 & 0.99 & 3.22 & 0.96 & 0.57 & 1.37 & 0.88 & 1.12 & 1.19 & 0.68 & 1.00 & 1.06 & 0.79 & 1.41 & 0.89 & 7.28 \\
\hline Hysterangium coriaceum & & 1.35 & 0.23 & 0.77 & 0.54 & 0.38 & 0.43 & 0.34 & 0.44 & 0.45 & 0.2 & 0.42 & 0.43 & 0.34 & 0.45 & 0.34 & 2.88 \\
\hline \multirow[t]{2}{*}{ Hysterangium $\mathrm{sp}(\mathrm{N}=2)$} & Mean & 2.02 & 0.38 & 1.41 & 0.73 & 0.48 & 1.44 & 0.55 & 0.72 & 0.68 & 0.35 & 0.62 & 0.71 & 0.54 & 0.76 & 0.49 & 4.49 \\
\hline & sd & 0.10 & 0.01 & 0.12 & 0.04 & 0.01 & 0.07 & 0.21 & 0.21 & 0.17 & 0.28 & 0.09 & 0.01 & 0.04 & 0.07 & 0.06 & 0.28 \\
\hline Mesophellia glauca & & 1.26 & 0.3 & 0.99 & 0.49 & 0.32 & 0.52 & 0.29 & 0.38 & 0.3 & 0.31 & 0.34 & 0.45 & 0.35 & 0.54 & 0.27 & 2.87 \\
\hline \multirow[t]{2}{*}{ Protoglossum sp (N=3) } & Mean & 1.13 & 0.68 & 1.9 & 0.69 & 0.46 & 0.71 & 0.64 & 0.76 & 0.64 & 0.44 & 0.68 & 0.59 & 0.56 & 0.91 & 0.6 & 4.88 \\
\hline & sd & 0.21 & 0.11 & 0.47 & 0.12 & 0.14 & 0.2 & 0.13 & 0.14 & 0.13 & 0.09 & 0.11 & 0.14 & 0.1 & 0.16 & 0.12 & 0.99 \\
\hline Rhizopogon hawkerae (immature) & & 1.23 & 0.74 & 2.25 & 0.56 & 0.24 & 0.62 & 0.57 & 0.78 & 0.78 & 0.4 & 0.47 & 0.67 & 0.38 & 0.7 & 0.4 & 3.83 \\
\hline Rhizopogon hawkerae (mature) & & 0.16 & 0.1 & 0.25 & 0.1 & 0.54 & 0.09 & 0.05 & 0.1 & 0.09 & 0.11 & 0.06 & 0.08 & 0.05 & 0.06 & 0.03 & 0.98 \\
\hline Rhizopogon villosulus & Mean & 1.15 & 0.58 & 1.87 & 0.5 & 0.22 & 0.53 & 0.52 & 0.69 & 0.75 & 0.32 & 0.53 & 0.62 & 0.43 & 0.7 & 0.39 & 3.73 \\
\hline \multirow[t]{2}{*}{ (immature) $(N=4)$} & sd & 0.26 & 0.14 & 0.74 & 0.12 & 0.07 & 0.24 & 0.17 & 0.17 & 0.16 & 0.09 & 0.2 & 0.15 & 0.17 & 0.25 & 0.13 & 1.23 \\
\hline & CV\% & 25 & 14 & 25 & 13 & 28 & 46 & 33 & 14 & 18 & 27 & 37 & 25 & 44 & 35 & 34 & 30 \\
\hline Rhizopogon villosulus & Mean & 1.07 & 0.40 & 1.08 & 0.37 & 0.15 & 0.38 & 0.42 & 0.49 & 0.56 & 0.25 & 0.44 & 0.53 & 0.35 & 0.53 & 0.30 & 2.96 \\
\hline (mature) $(\mathrm{N}=2)$ & sd & 0.05 & 0.04 & 0.11 & 0.03 & 0.01 & 0.03 & 0.02 & 0.02 & 0.08 & 0.03 & 0.04 & 0.04 & 0.03 & 0.02 & 0.17 & 0.38 \\
\hline Rhizopogon vinicolor (mature) & & 0.64 & 0.37 & 1.28 & 0.33 & 0.16 & 0.43 & 0.36 & 0.38 & 0.46 & 0.21 & 0.38 & 0.34 & 0.33 & 0.47 & 0.26 & 2.51 \\
\hline Setchelliogaster sp & & 1.71 & 0.94 & 2.4 & 1.11 & 0.51 & 1.24 & 0.92 & 1.1 & 0.95 & 0.64 & 1.03 & 0.72 & 0.82 & 1.33 & 0.94 & 6.91 \\
\hline Truncocolumella citrina (immature) & & 0.99 & 0.53 & 1.54 & 0.51 & 0.2 & 0.52 & 0.52 & 0.62 & 0.6 & 0.33 & 0.58 & 0.38 & 0.5 & 0.77 & 0.43 & 3.71 \\
\hline Truncocolumella citrina (mature) & & 0.83 & 0.45 & 1.21 & 0.43 & 0.15 & 0.31 & 0.45 & 0.49 & 0.44 & 0.25 & 0.45 & 0.25 & 0.37 & 0.61 & 0.36 & 2.89 \\
\hline \multicolumn{18}{|l|}{ Epigeous species } \\
\hline Agaricus bisporus & & 1.36 & 0.85 & 2.88 & 0.8 & 0.45 & 0.84 & 0.82 & 0.87 & 1.53 & 0.53 & 0.83 & 0.9 & 0.64 & 1.12 & 0.69 & 5.98 \\
\hline Agaricus xanthodermus & & 2.33 & 1.21 & 4.76 & 1.73 & 0.96 & 1.7 & 1.35 & 2.19 & 5.7 & 1.03 & 1.73 & 1.87 & 1.33 & 2.3 & 1.57 & 12.14 \\
\hline Boletus edulis & & 1.91 & 1.04 & 3.77 & 0.94 & 0.41 & 0.77 & 0.81 & 1.47 & 1.46 & 0.6 & 0.56 & 1.14 & 0.61 & 1.08 & 0.56 & 5.77 \\
\hline Boletus edulis & & 2.65 & 1.36 & 5.4 & 1.4 & 0.73 & 1.63 & 1.37 & 1.94 & 1.74 & 0.86 & 1.52 & 1.58 & 1.12 & 1.96 & 1.07 & 10.21 \\
\hline Boletus mirabilis & & 1.31 & 0.74 & 2.22 & 0.66 & 0.26 & 0.6 & 0.46 & 0.81 & 1.47 & 0.41 & 0.47 & 0.74 & 0.4 & 0.68 & 0.37 & 3.79 \\
\hline Boletus mirabilis & & 1.84 & 0.97 & 2.84 & 0.91 & 0.5 & 1.16 & 1.06 & 1.12 & 1.78 & 0.61 & 1.17 & 1.01 & 0.85 & 1.35 & 0.79 & 7.34 \\
\hline \multirow[t]{3}{*}{ Cantharellus formosus ( $N=5$ ) } & Mean & 0.93 & 0.54 & 1.37 & 0.56 & 0.25 & 0.67 & 0.56 & 0.64 & 0.76 & 0.34 & 0.59 & 0.47 & 0.55 & 0.81 & 0.51 & 4.08 \\
\hline & sd & 0.13 & 0.05 & 0.2 & 0.1 & 0.05 & 0.14 & 0.05 & 0.07 & 0.2 & 0.07 & 0.07 & 0.06 & 0.09 & 0.09 & 0.09 & 0.57 \\
\hline & CV\% & 14 & 9 & 15 & 18 & 20 & 21 & 9 & 11 & 26 & 21 & 12 & 13 & 16 & 11 & 18 & 14 \\
\hline \multirow[t]{3}{*}{ Cantharellus subalbidus } & Mean & 0.62 & 0.43 & 0.84 & 0.43 & 0.21 & 0.42 & 0.42 & 0.46 & 0.52 & 0.27 & 0.43 & 0.30 & 0.45 & 0.62 & 0.40 & 3.09 \\
\hline & sd & 0.03 & 0.03 & 0.06 & 0.02 & 0.01 & 0.05 & 0.03 & 0.02 & 0.11 & 0.01 & 0.01 & 0.01 & 0.01 & 0.03 & 0.01 & 0.13 \\
\hline & & & & & & & & & & & & & & & \multicolumn{3}{|c|}{ (continued on next page) } \\
\hline
\end{tabular}


Table 4 - (continued)

\begin{tabular}{|c|c|c|c|c|c|c|c|c|c|c|c|c|c|c|c|c|c|}
\hline Species & & $\mathrm{Asp}^{\mathrm{a}}$ & Ser & Glu & Gly & His & Arg & Thr & Ala & Pro & Tyr & Val & Lys & Ile & Leu & Phe & $\mathrm{EAA}^{\mathrm{b}}$ \\
\hline Lentinula edodes & & 1.86 & 1.11 & 5.01 & 1.11 & 0.65 & 1.03 & 1.2 & 2.53 & 2.82 & 0.51 & 1.28 & 1.17 & 0.96 & 1.59 & 0.99 & 8.35 \\
\hline \multirow[t]{3}{*}{ Morchella elata $(N=6)$} & Mean & 1.19 & 0.63 & 1.86 & 0.65 & 0.26 & 0.94 & 0.6 & 0.85 & 0.75 & 0.38 & 0.48 & 0.78 & 0.39 & 0.64 & 0.38 & 3.95 \\
\hline & sd & 0.42 & 0.2 & 0.46 & 0.15 & 0.09 & 0.33 & 0.32 & 0.22 & 0.36 & 0.13 & 0.3 & 0.24 & 0.23 & 0.31 & 0.2 & 1.82 \\
\hline & CV\% & 35 & 32 & 25 & 23 & 35 & 35 & 53 & 26 & 48 & 34 & 63 & 31 & 59 & 48 & 53 & 47 \\
\hline \multirow[t]{3}{*}{ Tricholoma magnivelare $(N=11)$} & Mean & 0.99 & 0.52 & 1.6 & 0.5 & 0.21 & 0.55 & 0.5 & 0.63 & 0.62 & 0.32 & 0.51 & 0.51 & 0.47 & 0.68 & 0.41 & 3.61 \\
\hline & sd & 0.24 & 0.1 & 0.42 & 0.09 & 0.05 & 0.15 & 0.11 & 0.12 & 0.14 & 0.05 & 0.12 & 0.12 & 0.1 & 0.14 & 0.08 & 0.77 \\
\hline & $\mathrm{CV} \%$ & 24 & 19 & 26 & 18 & 24 & 27 & 22 & 19 & 23 & 16 & 24 & 24 & 21 & 21 & 20 & 21 \\
\hline \multicolumn{18}{|l|}{ Descriptive statistics } \\
\hline \multirow[t]{5}{*}{ Hypogeous species } & Mean & 1.14 & 0.53 & 1.63 & 0.57 & 0.34 & 0.66 & 0.51 & 0.65 & 0.62 & 0.35 & 0.55 & 0.52 & 0.44 & 0.71 & 0.44 & 3.86 \\
\hline & sd & 0.49 & 0.27 & 0.85 & 0.26 & 0.17 & 0.42 & 0.25 & 0.31 & 0.30 & 0.17 & 0.27 & 0.28 & 0.22 & 0.39 & 0.26 & 1.89 \\
\hline & CV & 43 & 51 & 52 & 46 & 50 & 64 & 49 & 48 & 48 & 49 & 49 & 54 & 50 & 55 & 59 & 49 \\
\hline & Min & 0.16 & 0.10 & 0.25 & 0.10 & 0.06 & 0.09 & 0.05 & 0.10 & 0.09 & 0.10 & 0.06 & 0.08 & 0.05 & 0.06 & 0.03 & 0.81 \\
\hline & $\operatorname{Max}$ & 2.02 & 0.99 & 3.36 & 1.11 & 0.58 & 1.44 & 0.92 & 1.29 & 1.19 & 0.68 & 1.03 & 1.07 & 0.82 & 1.44 & 0.94 & 7.28 \\
\hline \multirow[t]{10}{*}{ Epigeous species } & Mean & 1.58 & 0.82 & 3.03 & 0.93 & 0.48 & 1.02 & 0.89 & 1.29 & 1.85 & 0.54 & 0.99 & 1.00 & 0.80 & 1.28 & 0.78 & 6.77 \\
\hline & sd & 0.72 & 0.29 & 1.66 & 0.45 & 0.27 & 0.47 & 0.39 & 0.76 & 1.64 & 0.26 & 0.53 & 0.54 & 0.37 & 0.65 & 0.40 & 3.36 \\
\hline & $\mathrm{CV}$ & 46 & 35 & 55 & 48 & 56 & 46 & 44 & 59 & 89 & 48 & 54 & 54 & 46 & 51 & 51 & 50 \\
\hline & Min & 0.62 & 0.43 & 0.84 & 0.43 & 0.20 & 0.42 & 0.42 & 0.46 & 0.52 & 0.27 & 0.43 & 0.30 & 0.39 & 0.62 & 0.38 & 3.09 \\
\hline & $\operatorname{Max}$ & 2.57 & 1.21 & 5.01 & 1.73 & 0.96 & 1.70 & 1.36 & 2.53 & 5.70 & 1.03 & 1.73 & 1.87 & 1.33 & 2.30 & 1.57 & 12.14 \\
\hline & $F_{1,24}$ & 2.88 & 6.42 & 8.17 & 6.77 & 2.50 & 4.18 & 8.00 & 9.22 & 11.9 & 5.60 & 8.09 & 8.91 & 9.54 & 7.89 & 7.00 & 8.07 \\
\hline & $P$ & 0.10 & 0.02 & 0.01 & 0.02 & 0.13 & 0.05 & 0.01 & 0.01 & 0.01 & 0.03 & 0.01 & 0.01 & 0.01 & 0.01 & 0.01 & 0.01 \\
\hline & lsd (5 \%) & & 0.24 & 1.01 & 0.28 & & 0.37 & 0.26 & 0.43 & 0.83 & 0.17 & 0.32 & 0.33 & 0.24 & 0.42 & 0.27 & 2.11 \\
\hline & & 0.61 & 0.66 & 0.66 & 0.77 & 0.59 & 0.68 & 0.69 & 0.56 & 0.72 & 0.84 & 0.70 & 0.82 & 0.69 & 0.74 & 0.76 & 0.77 \\
\hline & $F_{1,21}{ }^{\mathrm{c}}$ & 33 & 41 & 42 & 72 & 31 & 44 & 45 & 27 & 54 & 107 & 48 & 98 & 46 & 60 & 66 & 70 \\
\hline
\end{tabular}

b EAA is the sum of the essential AAs.

a asp (aspartic acid, non-essential), ser (serine, NE), glu (glutamic acid, NE), gly (glycine, NE), his (histidine, E), arg (arginine, NE but see text), thr (threonine, E), ala (alanine, NE), pro (proline, NE), tyr (tyrosine, E but see text), val (valine, E), lys (lysine, E) ile (isoleucine, E), leu (leucine, E), phe (phenylalanine, E).

C $r^{2}$ and $F$ : the coefficient of determination between the concentration of an AA and total nitrogen and the variance ratio $(F)$ for the relationship. All were highly significant $(P<0.0001)$. 
Table 5 - The quality of fungal protein, calculated from the amino acid (AA) pattern corrected for nitrogen digestibility, and expressed relative to that of ideal protein for growing rats.

\begin{tabular}{|c|c|c|c|c|c|c|c|c|c|}
\hline Species & & Arg & His & Ile & Leu & Lys & Phe + Tyr & Thr & Val \\
\hline \multicolumn{10}{|l|}{ Hypogeous } \\
\hline \multirow[t]{2}{*}{ Cortinarius globuliformis $(\mathrm{N}=2)$} & Mean & 58 & $19^{\mathrm{a}}$ & 37 & 51 & 47 & 61 & 41 & 38 \\
\hline & sd & 17 & 5 & 12 & 21 & 9 & 28 & 24 & 0 \\
\hline \multirow{2}{*}{ Gautieria monticola (mature) $(\mathrm{N}=2)$} & Mean & 61 & 48 & 50 & 36 & 24 & 42 & 42 & 39 \\
\hline & sd & 10 & 10 & 16 & 8 & 9 & 7 & 8 & 9 \\
\hline Hysterangium coriaceum & & 73 & 99 & 39 & 31 & 34 & 38 & 40 & 39 \\
\hline Hysterangium sp & & 87 & 48 & 25 & 20 & 21 & 23 & 25 & 24 \\
\hline Rhizopogon hawkerae (immature) & & 71 & 43 & 30 & 32 & 36 & 38 & 45 & 31 \\
\hline \multirow{2}{*}{ Rhizopogon villosulus (immat) $(\mathrm{N}=2)$} & Mean & 94 & 55 & 51 & 47 & 44 & 48 & 60 & 53 \\
\hline & sd & 5 & 4 & 1 & 3 & 5 & 1 & 1 & 2 \\
\hline \multirow[t]{2}{*}{ Rhizopogon villosulus (mature) $(\mathrm{N}=3$ ) } & Mean & 85 & 52 & 55 & 48 & 55 & 52 & 66 & 57 \\
\hline & sd & 4 & 2 & 3 & 2 & 7 & 2 & 6 & 3 \\
\hline Truncocolumella citrina (immature) & & 90 & 56 & 61 & 54 & 31 & 56 & 63 & 59 \\
\hline Truncocolumella citrina (mature) & & 68 & 50 & 56 & 54 & 26 & 56 & 69 & 58 \\
\hline \multicolumn{10}{|l|}{ Epigeous } \\
\hline Agaricus bisporus & & 58 & 57 & 38 & 36 & 31 & 110 & 47 & 42 \\
\hline Agaricus xanthodermus & & 82 & 73 & 45 & 45 & 42 & 190 & 46 & 49 \\
\hline Boletus edulis & & 112 & 74 & 64 & 57 & 55 & 53 & 61 & 67 \\
\hline \multirow{2}{*}{ Cantharellus formosus $(\mathrm{N}=3)$} & Mean & 80 & 49 & 50 & 40 & 26 & 46 & 48 & 43 \\
\hline & sd & 20 & 11 & 7 & 5 & 3 & 7 & 5 & 6 \\
\hline Cantharellus subalbidus & & 68 & 35 & 79 & 109 & 53 & 117 & 72 & 76 \\
\hline Lentinula edodes & & 103 & 87 & 55 & 55 & 52 & 90 & 70 & 60 \\
\hline \multirow[t]{2}{*}{ Tricholoma magnivelare $(\mathrm{N}=7)$} & Mean & 96 & 61 & 66 & 50 & 42 & 58 & 63 & 54 \\
\hline & sd & 14 & 9 & 16 & 9 & 3 & 9 & 10 & 12 \\
\hline \multicolumn{2}{|l|}{ Mean (hypogeous) } & 76 & 52 & 45 & 41 & 35 & 46 & 50 & 44 \\
\hline \multicolumn{2}{|l|}{ sd } & 13 & 21 & 13 & 12 & 12 & 12 & 15 & 13 \\
\hline \multicolumn{2}{|l|}{ Mean (epigeous) } & 86 & 62 & 57 & 56 & 43 & 95 & 58 & 56 \\
\hline \multicolumn{2}{|l|}{ sd } & 19 & 17 & 14 & 24 & 11 & 51 & 11 & 13 \\
\hline \multicolumn{2}{|l|}{$F_{1,14}$} & ns & ns & ns & ns & ns & 9.46 & ns & ns \\
\hline \multicolumn{2}{|l|}{$P$} & 0.26 & 0.31 & 0.10 & 0.12 & 0.20 & 0.008 & 0.25 & 0.09 \\
\hline \multicolumn{2}{|l|}{ Least significant difference (5 \%) } & & & & & & 3.6 & & \\
\hline
\end{tabular}

A bold font indicates the limiting AA.

a Arg-Arginine; His-Histidine; Ile-Isoleucine; Leu-Leucine; Lys-Lysine; Phe+Tyr-Phenylalanine+Tyrosine.

to assess whether animals maintained weight on the diets and whether they were in positive or negative $\mathrm{N}$ balance. Our results also indicate that the DMDs of fungi are similar to those of various plants fed to a wide range of ruminant species (Van Soest 1982). On this basis fungi appear to be a good source of available nutrients, so it is not surprising that mycophagy is such a common feeding strategy among mammals (Claridge \& May 1994; Maser et al. 1978).

Hypothesis (ii) that the AA content of fungi would vary highly was confirmed, as expected for various reasons. For instance, fungal sporocarps show tremendous morphological diversity and presumably different structures require different chemical buildingblocks and, in some cases, chemical defences. Epigeous fungi might use air currents to spread spores but they may also use animals. In contrast, many ectomycorrhizal fungi produce hypogeous sporocarps and rely on mycophagous animals to spread the spores (Claridge \& May 1994; Maser et al. 1978). The close evolutionary association among fungi, plants, and animals suggests that fungi might provide nutritional reward to animals for spreading spores. If so, we would expect the within-taxa variation in composition we saw for Tricholoma, Morchella, Cantharellus, and Rhizopogon. We might also expect some fungi to protect their protein, as we saw with one species, Hysterangium coriaceum, that appeared to produce tannin-like compounds that bind protein. Sporocarps also pass through stages of maturation and these too may affect nutrient concentrations. Finally, the nutritional composition of fungal sporocarps will also be partial reflection of the nutrient status of the soils they inhabit, and this can vary from one site to another. Regardless of the nutritional characteristic that we measured - for example $\mathrm{N}$ content, $\mathrm{N}$ digestibility, and the concentration of AAs, there was considerable variation among taxa, again in agreement with the findings of other researchers (e.g. Kalac 2009) and the in-vivo feeding studies mentioned previously (Cork \& Kenagy 1989; Claridge \& Cork 1994; Claridge et al. 1999; D'Alva et al. 2007; Dubay et al. 2008).

Hypothesis (iii) was that animals can counter the variability between fungal species in nutritional quality by eating a diversity of taxa (see Claridge \& Cork 1994; Claridge \& May 1994; Claridge et al. 1999; Maser et al. 1978). Analyses of faeces from mycophagous animals indicate this is the norm for obligate and preferential mycophagists and common with opportunistic mycophagists (Currah et al. 2000; Johnson 1994; Mangan \& Adler 2000; Maser et al. 1978; Seebeck et al. 1990; Tory et al. 1997; Vernes \& Dunn 2009). For example, the small obligate mycophagist, the California red-backed vole averaged five fungal species in its digestive tract, the result of foraging over the previous $24 \mathrm{~h}$ (Maser et al. 1978). A single sporocarp 
of many of those fungal species would fill their stomach several times over. Instead, digestive tracts from these voles contained smaller fragments of sporocarps from multiple species, highlighting their diverse foraging strategy. Over the course of a season, other mammal species have been recorded as eating up to 50 different species of fungi (e.g. Claridge \& May 1994). It is extremely difficult to replicate this strategy in feeding studies, which may explain why studies with one or two species of fungi sometimes indicate that fungi are of poor nutritional value (e.g. Cork \& Kenagy 1989; Dubay et al. 2008).

Evidence is growing that animals forage to satisfy a protein requirement - the protein leverage hypothesis (Felton et al. 2009; Sørensen et al. 2008). Animals, however, require EAAs, not protein (DeGabriel et al. 2002). Our results suggest that although fungi contain reasonable amounts of protein, the balance of digestible EAAs is poor, with lysine and leucine the most commonly limiting. To counteract this, an animal can adopt several strategies to improve the quality of its dietary protein. One strategy is to seek other food types with differing AAs to supplement those in fungi, e.g. insects: mycophagous animals are reported to eat fungi infested by insects (Bozinovic \& Muñoz-Pedreros 1995) and otherwise are known to feed on a range of invertebrates (Claridge \& May 1994).

Yet another approach to coping with imbalanced nutrients, particularly AAs, is to evolve appropriate metabolic and digestive strategies. Australia's potoroine (rat-kangaroo) marsupials are a prime example: they are among the smallest macropods (up to $3 \mathrm{~kg}$ with most less than $1 \mathrm{~kg}$ ), have foregut fermentation and low N requirements (Wallis 1994; Wallis \& Hume 1992). For these mycophagous animals, a key advantage is that microbes turn poor quality fungal protein into more readily available microbial protein. This protein turnover costs energy, but it is partly compensated by microbes also hydrolysing cell wall material and synthesising volatile fatty acids (Wallis 1994). Animals with hindgut fermentation can capture some of these advantages by practising caecotrophy or coprophagy (Liu et al. 2007; Soave \& Brand 1991), which is common among rodents, including voles (Nicodemus et al. 1999).

The combination of mycophagy, foregut fermentation and coevolution between animals and fungi may explain some Australian phenomena. Potoroine marsupials, obligate or preferential mycophagists, frequently occur in areas prone to fire (Claridge \& Trappe 2004). They often survive destructive fires and can maintain body mass on the limited selection of hypogeous fungi that remain immediately after disturbance (Johnson 1997; Vernes 2000; Vernes et al. 2004). These fungi are typically in the hypogeous family Mesophelliaceae, which survive when other, more fire-sensitive fungi temporarily stop fruiting (Claridge \& Trappe 2004; Trappe et al. 2006). Nothing in our limited analyses of only one sample of Mesophelliaceae suggest an AA composition better than that of other fungi. In this situation, an animal would be unable to satisfy its EAA requirements simply by eating a broad range of taxa, but foregut fermentation would allow it to enhance protein quality. Wallabies, opportunistic mycophagists, are also common in fire affected sites and forage for members of the Mesophelliaceae (Claridge et al. 2001). As opportunists, however, they can vary their diet by browsing plants that escaped the fire or by foraging in adjacent unburned areas where other species of fungi and browse vegetation are available.
In terms of broader aspects of mycophagist nutrition, fungal sporocarps are excellent sources of minerals, fats, vitamins and water in addition to AAs. Claridge \& Trappe (2005) and Maser et al. (2008) cover these nutritional aspects in detail. The data we present here round out the evidence for fungi as good, all-round nutritional sources. In conclusion, fungi are good source of nutrients that many animals use through possessing suitable metabolic and physiological adaptations. The co-evolutionary aspects are so strong that a tripartite relationship often exists between trees, animals, and ectomycorrhizal fungi (Claridge \& Trappe 2005; Maser et al. 2008; Trappe \& Claridge 2005). One outstanding question relating to the nutritional value of fungi is why so many mycophagous animals eat predominantly hypogeous fungi when so many epigeous species are often readily available in their habitats? Fungal toxins do not provide an adequate answer because one role of the foregut is microbial detoxification (Wallis 1994). One possible factor is that hypogeous fungi produce aromatic enticements that attract many kinds of animals (Claridge et al. 2010; Paull et al. 2011) whereas epigeous fungi may be primarily detected visually. Small mammals especially tend to forage by odours rather than by sight (Donaldson \& Stoddart 1994).

\section{Acknowledgements}

At the inception of this study, three personnel with the then CSIRO Division of Wildlife and Ecology participated: Trappe was a CSIRO McMasters Fellow, Dr Steve Cork provided encouragement, consultation and laboratory facilities, and Mandy Yialeloglou did the initial processing of the fungal collections. Trappe's participation was further supported in part by the USDA Forest Service, Pacific Northwest Station, Corvallis, Oregon, USA.

\section{R E F E R E N C E S}

Benevenga J, Gahl MJ, Crenshaw TD, Finke MD, 1994. Protein and amino acid requirements for maintenance and amino acid requirements for growth of laboratory rats. Journal of Nutrition 124: 451-453.

Bennett AF, Baxter BJ, 1989. Diet of the long-nosed potoroo, Potorous tridactylus, (Marsupialia: Potoroidae), in south-western Victoria. Australian Wildlife Research 16: 263-271.

Blaschke H, Baumler W, 1989. Mycophagy and spore dispersal by small mammals in Bavarian forests. Forest Ecology and Management 26: 237-245.

Boisen S, Hvelplund T, Weisbjerg MR, 2000. Ideal amino acid profiles as a basis for feed protein evaluation. Livestock Production Science 64: 239-251.

Bozinovic F, Muñoz-Pedreros A, 1995. Dieta mixta y energética nutricional de un roedor micófago en el sur de Chile: interacciones entre ítemes dietarios. Revista Chiena de Historia Natural 68: 383-389.

Buller AHR, 1909. Slugs and Hymenomycetes. Researches on Fungi 1: 226-230.

Claridge AW, Cork SJ, 1994. Nutritional value of hypogeal fungal sporocarps for the long-nosed potoroo (Potorous tridactylus), a forest-dwelling mycophagous marsupial. Australian Journal of Zoology 42: 701-710. 
Claridge AW, Cork SJ, Trappe JM, 2000. Diversity and habitat relationships of hypogeous fungi. I. Study design sampling techniques and general survey results. Biodiversity and Conservation 9: 151-173.

Claridge AW, May TW, 1994. Mycophagy among Australian mammals. Australian Journal of Ecology 19: 252-275.

Claridge AW, Trappe JM, 2004. Managing habitat for mycophagous (fungus-feeding) mammals: a burning issue? In: Lunney D (ed.), Conservation of Australia's Forest Fauna Royal Zoological Society of New South Wales, Mosman, Australia, pp. 937-946.

Claridge AW, Paull DJ, Barry SC, 2010. Detection of medium ground-dwelling mammals using infrared digital cameras: an alternative way forward? Australian Mammalogy 32: 165-171.

Claridge AW, Trappe JM, 2005. Sporocarp mycophagy: nutritional, behavioural, evolutionary and physiological aspects. In: Dighton J, White JF, Oudemans P (eds), The Fungal Community Its Organization and Role in Ecosystems. Taylor \& Francis, Boca Raton, pp. 599-611.

Claridge AW, Trappe JM, Claridge DL, 2001. Mycophagy by the swamp wallaby (Wallabia bicolor). Wildlife Research 28: 643-645.

Claridge AW, Trappe JM, Cork SJ, Claridge DL, 1999. Mycophagy by small mammals in the coniferous forests of North America: nutritional value of sporocarps of Rhizopogon vinicolor, a common hypogeous fungus. Journal of Comparative Physiology [B] 169: 172-178.

Clauss M, Schwarm A, Ortmann S, Streich WJ, Hummel J, 2007. A case of non-scaling in mammalian physiology? Body size, digestive capacity, food intake, and ingesta passage in mammalian herbivores. Comparative Biochemistry and Physiology A 148: 249-265.

Cohen SA, Michaud DP, 1993. Synthesis of a fluorescent derivatising reagent, 6-aminoquinoyl- $N$-hydroxysuccinimydyl carbamate, and its application for the analysis of hydrolysate amino acids via high-performance liquid chromatography. Analytical Biochemistry 211: 279-287.

Cooper T, Vernes K, 2011. Mycophagy in the larger bodied skinks of the genera Tiliqua and Egernia: are there implications for ecosystem health? Australian Zoologist 35: 681-684.

Cork SJ, Kenagy GJ, 1989. Nutritional value of hypogeous fungus for a forest-dwelling ground squirrel. Ecology 70: 577-586.

Currah RS, Smreciu EA, Lehesvirta T, Niemi M, Larsen KW, 2000. Fungi in the winter diets of northern flying squirrels and red squirrels in the boreal mixedwood forest of northeastern Alberta. Canadian Journal of Botany 78: 1514-1520.

D'Alva T, Lara C, Estrada-Torres A, Castillo-Guevara C, 2007. Digestive responses of two omnivorous rodents (Peromyscus maniculatus and P. alstoni) feeding on epigeous fungus (Russula occidentalis). Journal of Comparative Physiology [B] 177: 707-712.

DeGabriel J, Foley WJ, Wallis IR, 2002. The effect of excesses and deficiencies of amino acids on the feeding behaviour of the common brushtail possum (Trichosurus vulpecula). Journal of Comparative Physiology [B] 172: 607-617.

DeGabriel JL, Wallis IR, Moore BD, Foley WJ, 2008. A simple, integrative assay to quantify nutritional quality of browses for herbivores. Oecologia 156: 107-116.

Dodd CKJ, 2002. North American Box Turtles - a Natural History. University of Oklahoma Press, Norman.

Donaldson R, Stoddart M, 1994. Detection of hypogeous fungi by the Tasmanian bettong (Bettongia gaimardi: Marsupialia; Macropodoidea). Journal of Chemical Ecology 20: 1201-1207.

Dubay SA, Hayward GD, del Rio CM, 2008. Nutritional value and diet preference of arboreal lichens and hypogeous fungi for small mammals in the Rocky mountains. Canadian Journal of Zoology 86: 851-862.

Faichney GJ, White GA, 1983. Methods for the Analysis of Feeds Eaten by Ruminants. CSIRO, Melbourne.
Felton AM, Felton A, Raubenheimer D, Simpson SJ, Foley WJ, Wood JT, Wallis IR, Lindenmayer DB, 2009. Protein content of diets dictates the daily energy intake of a free-ranging primate. Behavioural Ecology 20: 685-690.

Flaherty EA, Ben-David M, Smith WP, 2010. Diet and food availability: implications for foraging and dispersal of Prince of Wales northern flying squirrels across managed landscapes. Journal of Mammalogy 91: 79-91.

Fogel R, Trappe JM, 1978. Fungus consumption (mycophagy) by small mammals. Northwest Science 52: 1-31.

Gioacchini AM, Menotta M, Bertini L, Rossi I, Zeppa S, Zambonelli A, Piccoli G, Stocchi V, 2005. Solid-phase microextraction gas chromatography/mass spectrometry: a new method for species identification of truffles. Rapid Communications in Mass Spectrometry 19: 2365-2370.

Goering HK, Van Soest PJ, 1970. Forage Fiber Analysis. Agricultural Handbook No. 379. United States Department of Agriculture, WashingtonD.C.

Grönwall O, Pehrson A, 1984. Nutrient content in fungi as a primary food of the red squirrel Sciurus vulgaris L. Oecologia 64: 230-231.

Hanson AM, Hall MB, Porter LM, Lintzenich B, 2006. Composition and nutritional characteristics of fungi consumed by Callimico goeldii in Pando, Bolivia. International Journal of Primatology 27: 323-346.

Hanya G, 2004. Diet of a Japanese macaque troop in the coniferous forest of Yakushima. International Journal of Primatology 25: 55-71.

Hardy GA, 1949. Squirrel cache of fungi. Canadian Field Naturalist 63: 86-87.

Hochberg ME, Bertault G, Poitrineau K, Janssen A, 2003. Olfactory orientation of the truffle beetle, Leiodes cinnamomea. Entomologia Experimentalis et Applica 109: 147-153.

Johnson CN, 1994. Mycophagy and spore dispersal by a rat-kangaroo-consumption of ectomycorrhizal taxa in relation to their abundance. Functional Ecology 8: 464-468.

Johnson CN, 1996. Interactions between mammals and ectomycorrhizal fungi. Trends In Ecology and Evolution 11: 503-507.

Johnson CN, 1997. Fire and habitat management for a mycophagous marsupial, the Tasmanian bettong Bettongia gaimardi. Australian Journal of Ecology 22: 101-105.

Jones JD, Wolters R, Burnett PC, 1966. Lysine-arginine-electrolyte relationships in the rat. Journal of Nutrition 89: 171-188.

Kalac P, 2009. Chemical composition and nutritional value of European species of wild growing mushrooms: a review. Food Chemistry 113: 9-16.

Karlovsky P, 2008. Secondary Metabolites in Soil Ecology. Springer, New York.

Lehmkuhl JE, Gould LE, Cázares E, Hosford DR, 2004. Truffle abundance and mycophagy by northern flying squirrels in eastern Washington forests. Forest Ecology and Management 200: 49-65.

Liu QS, Li JY, Wang DH, 2007. Ultradian rhythms and the nutritional importance of caecotrophy in captive Brandt's voles (Lasiopodomys brandtii). Journal of Comparative Physiology [B] 177: 423-432.

Llames CR, Fontaine J, 1994. Determination of amino acids in feeds: collaborative study. Journal of the Association of Official Agricultural Chemists International 77: 1362-1402.

Mangan SA, Adler GH, 2000. Consumption of arbuscular mycorrhizal fungi by terrestrial and arboreal small mammals in a Panamanian cloud forest. Journal of Mammalogy 81: 563-570.

Maser C, Claridge AW, Trappe JM, 2008. Trees, Truffles and Beasts-How Forests Function. Rutgers University Press, New Brunswick, New Jersey.

Maser C, Trappe JM, Nussbaum RA, 1978. Fungal-small mammal interrelationships with particular emphasis on Oregon coniferous forests. Ecology 59: 799-809. 
Maser Z, Maser C, Trappe JM, 1985. Food habits of northern flying squirrels (Glaucomys sabrinus) in Oregon. Canadian Journal of Zoology 63: 1084-1088.

McGraw R, Duncan N, Cázares E, 2002. Fungi and other items consumed by the blue-gray taildropper slug (Prophysaon coeruleum) and the papillose taildropper slug (Prophysaon dubium) based on fecal analysis. The Veliger 45: 261-264.

Mitchell D, 2001. Spring and fall diet of the endangered West Virginia northern flying squirrel (Glaucomys sabrinus fuscus). American Midland Naturalist 146: 439-443.

Newton AF, 1984. Mycophagy in Staphylinoidea (Coleoptera). In: Wheeler Q Blackwell M (eds), Fungus-Insect Relationships. Perspectives in Ecology and Evolution. ColumbiaUniversity Press, New York, pp. 302-353.

Nicodemus N, Mateos J, de Blas JC, Carabano R, Fraga MJ, 1999. Effect of diet on amino acid composition of soft faeces and the contribution of soft faeces to total amino acid intake, through caecotrophy in lactating doe rabbits. Animal Science 69: 167-170.

NRC, 1995. Nutrient Requirements of Laboratory Animals. National Academy of Sciences, Washington, D. C.

Paull DJ, Claridge AW, Barry SC, 2011. There's no accounting for taste: bait attractants and infrared digital cameras for detecting small to medium ground-dwelling mammals. Wildlife Research 38: 188-195.

Perez Calvo J, Maser Z, Maser C, 1989. Note on fungi in small mammals from the Nothofagus forest in Argentina. Great Basin Naturalist 49: 618-620.

Pyare S, Longland WS, 2001. Mechanisms of truffle detection by northern flying squirrels. Canadian Journal of Zoology 79: 1007-1015.

Seebeck JH, Bennett AF, Scotts DH, 1990. Ecology of the potoroidae. In: Grigg GC, Jarman PJ, Hume ID (eds), Kangaroos, Wallabies and Rat-Kangaroos. Surrey-Beatty \& Sons, Sydney, pp. 67-88.

Simpson JA, 2000. More on mycophagous birds. Australasian Mycologist 19: 49-51.

Singer R, 1961. Mushrooms and Truffles. Interscience, New York.

Soave O, Brand CD, 1991. Coprophagy in animals-a review. Cornell Veterinarian 81: 357-364.

Sørensen A, Mayntz D, Raubenheimer D, Simpson SJ, 2008. Protein-leverage in mice: the geometry of macronutrient balancing and consequences for fat deposition. Obesity 16 : 566-571.

Splivallo R, Ottonello S, Mello A, Karlovsky P, 2010. Truffle volatiles: from chemical ecology to aroma biosynthesis. New Phytologist 189: 688-699.
Sutherland AM, Parrella MP, 2009. Mycophagy in Coccinellidae: review and synthesis. Biological Control 51: 284-293.

Tory MK, May TW, Keane PJ, Bennett AF, 1997. Mycophagy in small mammals: a comparison of the occurrence and diversity of hypogeal fungi in the diet of the long-nosed potoroo Potorous tridactylus and the bush rat Rattus fuscipes from southwestern Victoria, Australia. Australian Journal of Ecology 22: $460-470$.

Trappe JM, Claridge AW, 2005. Hypogeous fungi: evolution of reproductive and dispersal strategies through interactions with animals and mycorrhizal plants. In: Dighton J, White JF, Oudemans P (eds), The Fungal Community - its Organization and Role in the Ecosystem. Taylor and Francis, Boca Raton, Florida, pp. 613-623.

Trappe JM, Nicholls AO, Claridge AW, Cork SJ, 2006. Prescribed burning in a Eucalyptus woodland suppresses fruiting of hypogeous fungi, an important food source for mammals. Mycological Research 110: 1333-1339.

Van Soest PJ, 1982. Nutritional Ecology of the Ruminant. O \& B Books, Corvallis, Oregon.

Vernes K, 2000. Immediate effects of fire on survivorship of the northern bettong (Bettongia tropica): an endangered Australian marsupial. Biological Conservation 96: 305-309.

Vernes K, Dunn L, 2009. Mammal mycophagy and fungal spore dispersal across a steep environmental gradient in eastern Australia. Australian Ecologist 34: 69-76.

Vernes K, Johnson CN, Castellano MA, 2004. Fire-related changes in biomass of hypogeous sporocarps at foraging points used by a tropical mycophagous marsupial. Mycological Research 108: $1438-1446$

Vernes K, Poirier N, 2007. Use of a robin's nest as a cache site for truffles by a red squirrel. Northeastern Naturalist 14: 145-149.

Wallis IR, 1994. The rate of passage of digesta through the gastrointestinal tracts of potoroine marsupials - more evidence about the role of the potoroine foregut. Physiological Zoology 67: 771-795.

Wallis IR, Hume ID, 1992. The maintenance nitrogen requirements of potoroine marsupials. Physiological Zoology 65 1246-1270.

Williams CH, Twine RJ, 1967. Determination of Nitrogen, Sulphur, Phosphorus, Potassium, Sodium, Calcium and Magnesium in Plant Material by Automatic Analysis. CSIRO Division of Plant Industry Technical Paper 24, Canberra.

Witte V, Maschwitz U, 2008. Mushroom harvesting ants in the tropical rain forest. Naturwissenschaften 95: 1049-1054. 